\title{
Klasifikasi Jenis dan Sebaran Sedimen Menggunakan Data Multibeam Echosounder Multi-Temporal di Alur Pelayaran Barat dan Timur Surabaya
}

\author{
(Classification of Type and Distribution of Sediment Using Multi-Temporal Data of Multibeam \\ Echosounder on West and East Access Channels of Surabaya Port)
}

\author{
Fadilla Ivana Ayuningtyas ${ }^{1}$, Bambang Kun Cahyono ${ }^{2}$ \\ ${ }^{1}$ Alumni Departemen Teknik Geodesi FT Universitas Gadjah Mada, Indonesia \\ 2 Staf Pengajar Departemen Teknik Geodesi FT Universitas Gadjah Mada, Indonesia
}

Penulis Korespondensi: Bambang Kun Cahyono | Email: bambangkun@ugm.ac.id

Diterima (Received): 31/12/2020 Direvisi (Revised): 15/12/2021 Diterima untuk Publikasi (Accepted): 20/12/2021

\begin{abstract}
ABSTRAK
Pelabuhan Tanjung Perak Surabaya merupakan salah satu pelabuhan utama di Indonesia yang memiliki peran penting dalam transportasi laut Indonesia. Survei batimetri rutin diperlukan untuk mengidentifikasi kedalaman alur akses pelabuhan dan kondisi sedimentasi yang terjadi. Kondisi sedimen dapat dikarakterisasi berdasarkan sifat alaminya: ukuran butir, berat jenis, kecepatan jatuh, komposisi, porositas, bentuk, dll. Kondisi sedimen juga dapat dikarakterisasi berdasarkan nilai hamburan balik sonar, menggunakan instrumen Multibeam Echosounder (MBES) . Data mentah nilai hamburan balik kemudian dikoreksi dengan mengadopsi persamaan regangan kontras linier ke kisaran tertentu. Data masukan penelitian ini diukur menggunakan ODOM MB2 dengan instrumen Applanix oleh The Surabaya Navigational District (DISNAV) pada bulan Februari 2019 (Lokasi 2) dan Oktober 2018 (Lokasi 1) untuk alur akses barat Surabaya (APBS) dan Agustus 2017 ( Lokasi 3) untuk jalur akses timur Surabaya (APTS). Uji kualitas data batimetri dilakukan dengan mengikuti IHO S-44 2008 untuk spesifikasi pesanan khusus. Hasil penelitian menunjukkan bahwa data batimetri memiliki akurasi yang baik pada lokasi 1, 2, dan 3 dengan nilai 0,0862; 0,1317; dan 0,1072. Hubungan antara tipe sedimen dan hamburan balik menunjukkan bahwa tipe sedimen pasir memberikan hamburan balik yang kuat. Semakin kecil nilai hamburan balik maka jenis sedimennya semakin lunak. Klasifikasi di APBS dan APTS menunjukkan bahwa di APBS terdiri dari empat jenis sedimen (lempung, lanau lempung, lanau berpasir, dan pasir) sedangkan di APTS hanya terdapat tiga jenis sedimen (lanau lempung, lanau berpasir, dan pasir).
\end{abstract}

Kata Kunci: Backscatter, multibeam echosounder, klasifikasi sedimen, sebaran sedimen

\section{ABSTRACT}

Tanjung Perak Surabaya Port is one of the principal harbors in Indonesia, which has an essential role in Indonesian sea transportation. Periodic bathymetric surveys are needed to identify the depth of the port's access channel and sedimentation condition that occurs. The sediment condition can be characterized according to their natural properties: the grain size, density, fall speed, composition, porosity, shape, etc. The sediment condition can also be characterized based on the value of sonar backscatter, using Multibeam Echosounder (MBES) instrument. The raw data of backscatter value is then corrected by adopting the linear contrast stretch equation to a certain range. The input data of this research was measured using the ODOM MB2 with Applanix instrument by The Surabaya Navigational District (DISNAV) in February 2019 (Location 2) and October 2018 (Location 1) for the west access channel of Surabaya (APBS) and August 2017 (Location 3) for the east access channels of Surabaya (APTS). The bathymetric data quality test was performed by following the IHO S-44 2008 for special order specification. The results show that the bathymetric data has a proper accuracy in locations 1, 2, and 3 , with the values are 0.0862, 0.1317, and 0.1072. The sediment type and backscatter relationship shows that the sand sediment type provides a strong backscatter. The smaller value of backscatter, the softer type of sediment. When the classification was performed in $A P B S$ and APTS, it shows that the APBS consists of four types of sediment (clay, clayey silt, sandy silt, and sand). Meanwhile, in the APTS, there are only three types of sediment (clayey silt, sandy silt, and sand).

Keywords: Backscatter, multibeam echosounder, sediment classification, sediment distribution

(C) Author(s) 2021. This is an open access article under the Creative Commons Attribution-ShareAlike 4.0 International License (CC BY-SA 4.0). 


\section{Pendahuluan}

Pelabuhan Tanjung Perak Surabaya merupakan salah satu pelabuhan besar di Indonesia yang memiliki peranan penting di rute Tol Laut. Sehingga diperlukan pengukuran batimetri rutin setiap tahunnya untuk mengetahui jenis dan sebaran sedimentasi yang terjadi. Sedimen dasar perairan tersusun oleh pecahan batuan, mineral atau bahan organik yang ditransportasikan dari berbagai sumber secara vertikal maupun secara horizontal dan diendapkan oleh udara, air, dan es. Seluruh permukaan dasar laut ditutupi oleh partikelpartikel sedimen yang diendapkan secara perlahan-lahan dalam jangka waktu berjuta-juta tahun (Garrison, 2005). Sedimen yang merupakan partikel lepas (unconsolidated) yang terhampar di daratan, di pesisir, dan di laut tersebut berasal dari batuan atau material yang mengalami proses pelapukan, peluluhan, pengangkutan, dan pengendapan. Endapan sedimen dapat dikelompokkan sebagai endapan klastik, seperti endapan pasir, lanau, lempung, dan endapan campuran pasir dan lanau. Sedimen dicirikan atau dikarakterisasi menurut sifat-sifat alami yang dimilikinya yaitu misalnya: ukuran butir (grain size), densitas, kecepatan jatuh, komposisi, porositas, bentuk dan sebagainya. Berdasarkan ukuran butirnya, sedimen diklasifikasikan menurut: lumpur ( $m u d$ ), pasir (sand), dan kerikil (gravel) (Poerbandono \& Djunarsjah, 2005)

Secara konvensional, sifat-sifat sedimen dasar laut diperoleh dari hasil sampel coring dan sedimen grab. Namun cara ini bersifat lambat, mahal, memerlukan banyak tenaga, dan tidak memberikan pengumpulan data yang sifatnya real time atau in situ. Dengan menggunakan sistem akustik untuk klasifikasi sedimen dasar laut mampu memperkirakan secara akurat, mendekati real time, sifatsifat akustik, tipe sedimen, dan beberapa sifat geoteknik pada kedalaman beberapa meter dari dasar laut, pada saat survei sedang berlangsung (Kim, Richardson, Bibee, \& Wilkens, 2004). Klasifikasi sedimen dasar perairan dapat dilakukan berdasarkan nilai acoustic backscattering strengthnya. Pengukuran acoustic backscattering strength (backscatter) dasar perairan dapat dilakukan menggunakan instrumen multibeam echosounder (MBES). Dari hubungan ini dapat ditentukan tipe sedimen dasar perairan dimana tiap tipe sedimen yang berbeda biasanya menunjukkan tingkat intensitas yang berbeda, sehingga dapat digunakan untuk mengidentifikasi tipe dan penyebaran spasial morfologi dari sedimen dasar perairan (Hasan R Che, 2014). Backscatter juga ditentukan oleh sudut, sehingga dalam sebaran nilai hambur balik terdapat daerah yang dicirikan sebagai nadir stripping. Nadir stripping merupakan sinyal hambur balik di dalam daerah sudut datang vertikal dengan nilai yang lebih kuat (Parnum, Siwabessy, \& Gavrilov, 2004)

Kegiatan penelitian pemanfaatan backscatter klasifikasi jenis dan sebaran sedimen telah banyak dilakukan, diantaranya oleh Dartnell \& Gardner (2004), Goff et al. (2004), Ferrini \& Flood (2006), Supartono (2013), dan Nitriansyah \& Cahyono (2018). Dartnell \& Gardner (2004) melakukan penelitiannya di perairan dangkal 40-110 meter dengan menggunakan dua metode. Metode pertama yaitu dengan klasifikasi supervised terhadap ukuran butir dan lokasi sedimen, dan metode kedua yaitu dengan hierarki untuk klasifikasi batimetri dan backscatter. Dari kedua metode tersebut di dapat hasil korelasi antara nilai backscatter dengan substrat dasar perairan tipe batuan yang sangat tinggi. Goff et al. (2004) melakukan penelitian yang serupa di kedalaman 60-150 meter. Namun pada area penelitian nya memiliki nilai kemiringan rendah $\left(<1^{\circ}\right)$ yang mengakibatkan respon backscatter didominasi oleh sifat sedimen. Penelitian yang lain yang mempelajari tentang backscatter adalah Ferrini \& Flood (2006) yang melakukan penelitian di area sedimen dengan tekstur halus hingga sedang dimana area tersebut merupakan lokasi peselancar dan penangkapan ikan yang aktif. Penelitian backscatter ini dilakukan dengan dikaitkan pada kekasaran dasar laut dan ukuran butir. Sehingga didapatkan hasil berupa pola intensitas backscatter yang relatif tinggi yang konsisten terhadap pasir di dekat pantai, dan relatif rendah pada sedimen halus di lepas pantai. Hasil penelitian lain yang serupa juga didapat oleh Brown \& Collier, (2008) dan Sutherland et al., (2007) yaitu lingkungan berpasir cenderung lebih baik sebagai pantulan energi akustik, sementara lingkungan berlumpur cenderung buruk dalam pemantulan energi akustik.

Kemudian Supartono (2013) melakukan penelitian pengukuran acoustic backscattering strength dasar perairan di perairan Teluk Buyat. Dilakukan perbandingan nilai acoustic backscattering strength yang diperoleh oleh instrumen MBES dan singlebeam echosounder (SBES). Dari hasilnya dapat diketahui bahwa memang terdapat perbedaan nilai acoustic backscattering strength pada tipe substrat yang sama, yang terletak pada lokasi perairan yang berbeda yang dapat disebabkan oleh beberapa faktor, antara lain: frekuensi alat yang digunakan, sifat-sifat fisis dasar perairan, komposisi partikel penyusun sedimen dasar perairan, konfigurasi sonar (jarak dan beamwidth), kecepatan rambat gelombang akustik dalam kolom air, serta geometri pengukuran. Lalu Nitriansyah \& Cahyono (2018) juga melakukan penelitiannya di Pelabuhan Tanjung Perak Surabaya pada area dengan kedalaman 20 23 meter. Nitriansyah \& Cahyono (2018)membagi kelas sedimen berdasarkan respon backscatter menjadi 4 kelas yaitu clay, clayey silt, sandy silt, dan sand. Dari sampel sedimen yang dimiliki dilakukan uji sampel pengayakan (sieve) menggunakan metode American Society for Testing and Materials (ASTM). Selanjutnya dari persentase hasil ayakan sedimen pada masing-masing massa partikel yang tersaring, kemudian dimasukkan ke dalam tabel Grain Size dan ditentukan jenis tekstur sedimen menggunakan segitiga tekstur United States Department of Agriculture (USDA).

Melihat beberapa penelitian yang telah dilakukan sebelumnya maka di rasa perlu untuk memonitoring klasifikasi dan sebaran sedimen di Alur Pelayaran Barat 
dan Timur Surabaya secara rutin di tiap tahunnya. Kegiatan ini dilakukan pada lokasi Alur Pelayaran Barat dan Timur Surabaya yang selalu memiliki aktivitas kapal yang melintasi alur pelayaran tiap saat. Maka dilakukan pengkajian dengan data masukan berupa raw data hasil pengukuran Distrik Navigasi Kelas I Surabaya menggunakan instrumen MBES dengan Tipe ODOM MB2 with Aplanix di tahun akuisisi 2019, 2018, dan 2017.

\section{Data dan Metodologi}

\subsection{Data dan Lokasi}

Kegiatan ini dilakukan menggunakan tiga set data dengan tahun akuisisi dan lokasi yang berbeda (Gambar 1) yang berada di Alur Pelayaran Barat dan Timur Surabaya. Data yang digunakan dalam kegiatan ini terdiri atas data utama dan data pendukung. Data utama dalam penelitian ini yaitu:

1. Raw data dengan ekstensi *.s7k hasil pengukuran Distrik Navigasi (DISNAV) Kelas I Surabaya menggunakan instrumen MBES Tipe ODOM MB2 with Aplanix pada bulan Februari 2019 (Lokasi 2) dan Oktober 2018 (Lokasi 1) di Alur Pelayaran Barat Surabaya (APBS) dan Agustus 2017 (Lokasi 3) di Alur Pelayaran Timur Surabaya (APTS) dengan keseluruhan interval kedalaman data yaitu 3-34 meter dibawah permukaan laut.

2. Nilai koreksi Sound Velocity Profiler (SVP) hasil pengukuran DISNAV Kelas I Surabaya menggunakan instrumen Valeport Mini SVS dengan ekstensi *.txt pada kedalaman 0,5 meter hingga 9,5 meter dengan pertambahan kedalaman setiap 0,5 meter.

3. Nilai koreksi pergerakan kapal (pitch, roll, dan yaw) didapatkan dari data report pengukuran tiap set data yang dimiliki.

4. Nilai koreksi Total Propagated Uncertainty (TPU) didapatkan dari data spesifikasi alat survei yang digunakan.

5. Nilai koreksi pasang surut menggunakan data pasang surut prediksi yang didapatkan dari website Badan Informasi Geospasial (BIG) di titik pengamatan seperti yang disajikan pada Tabel 1.1.

Tabel 1.1 Koordinat titik BM pasang surut

\begin{tabular}{ccc}
\hline \multirow{2}{*}{ Set Data } & \multicolumn{2}{c}{ Koordinat (m) } \\
\cline { 2 - 3 } & Longitude & Latitude \\
\hline 2019 dan 2018 & 690527.86 BT & 9203472.41 LS \\
2017 & 701378.89 BT & 9235637.89 LS \\
\hline
\end{tabular}

\subsection{Metodologi}

Pada kegiatan ini, raw data hasil pengukuran MBES dengan ekstensi *.s7k diolah menggunakan software CARIS HIPS and SIPS versi 11.2 Training License. Dan untuk visualisasinya menggunakan software ArcGIS 10.6.1. Untuk kerangka kerja kegiatan, dipaparkan seperti pada Gambar 3.
Kerangka kerja tersebut terbagi menjadi beberapa tahapan yaitu;

\section{a. Pendefinisian Konfigurasi Kapal}

Pendefinisian konfigurasi kapal harus sesuai dengan keadaan kapal yang digunakan untuk akuisisi data. Pada tahapan ini dilakukan input data dimensi kapal, tanggal dalam Julian date, spesifikasi transducer, kalibrasi patch test (roll, yaw, pitch), dan Total Propagated Uncertainty (TPU). Dimasukkan pula nilai offset dari alat-alat survei terhadap titik yang menjadi reference point dengan ilustrasi seperti pada Gambar 2.

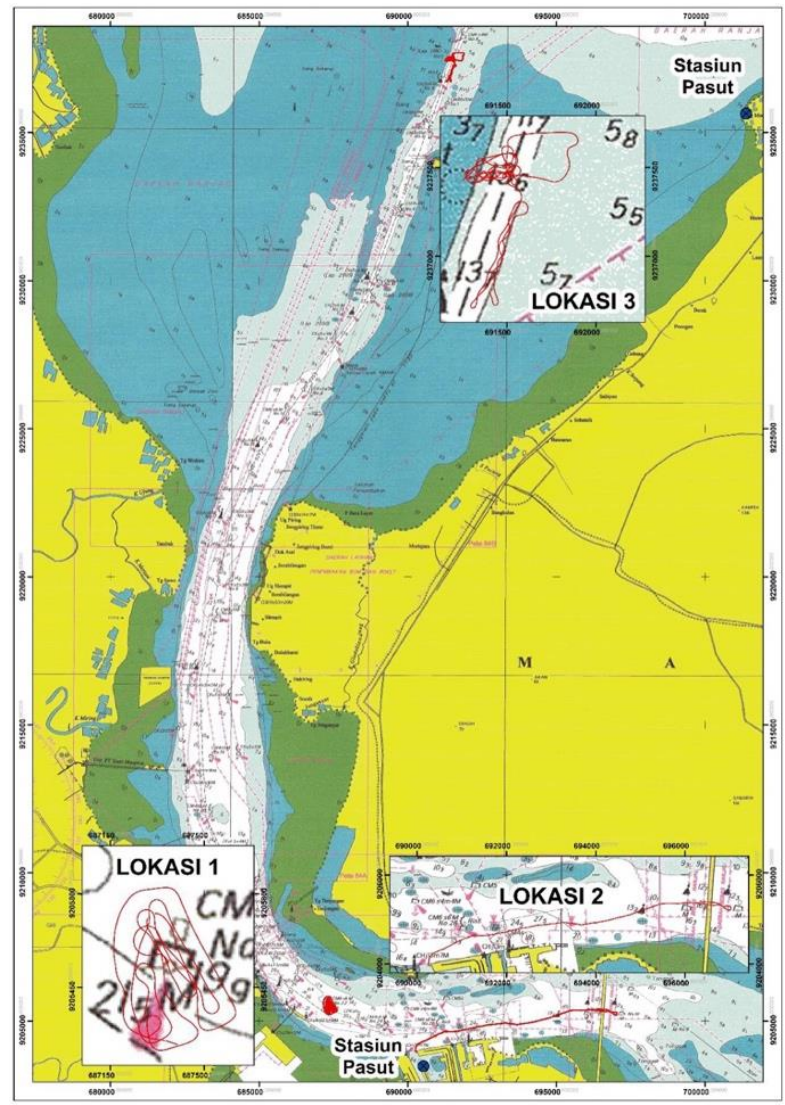

Gambar 1. Lokasi kegiatan dengan basemap Peta Laut No. 96 Surabaya (Sumber:PUSHIDROSAL, 2019)

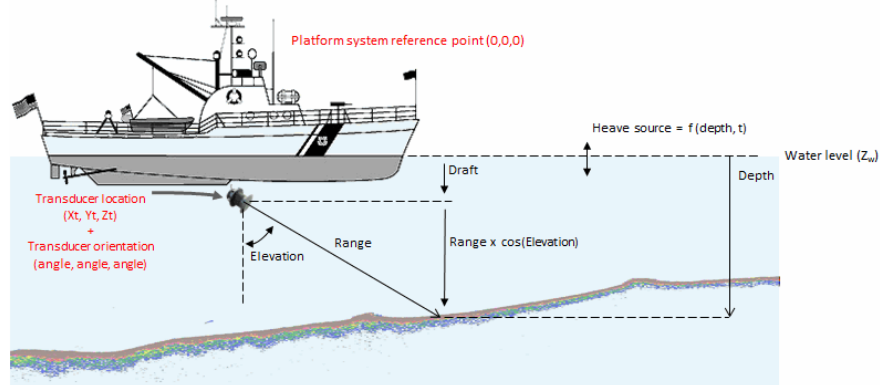

Gambar 2. Ilustrasi posisi peralatan survei terhadap reference point (Echoview $®$, 2021) 
Pada kegiatan pengukuran batimetri dapat dipastikan akan terdapat pengaruh pergerakan kapal yang diakibatkan oleh adanya dinamika laut. Maka dari itu digunakan sensor motion untuk mendeteksi pergerakan kapal (pitch, roll, yaw dan heave) tersebut yakni Motion Reference Unit (MRU).

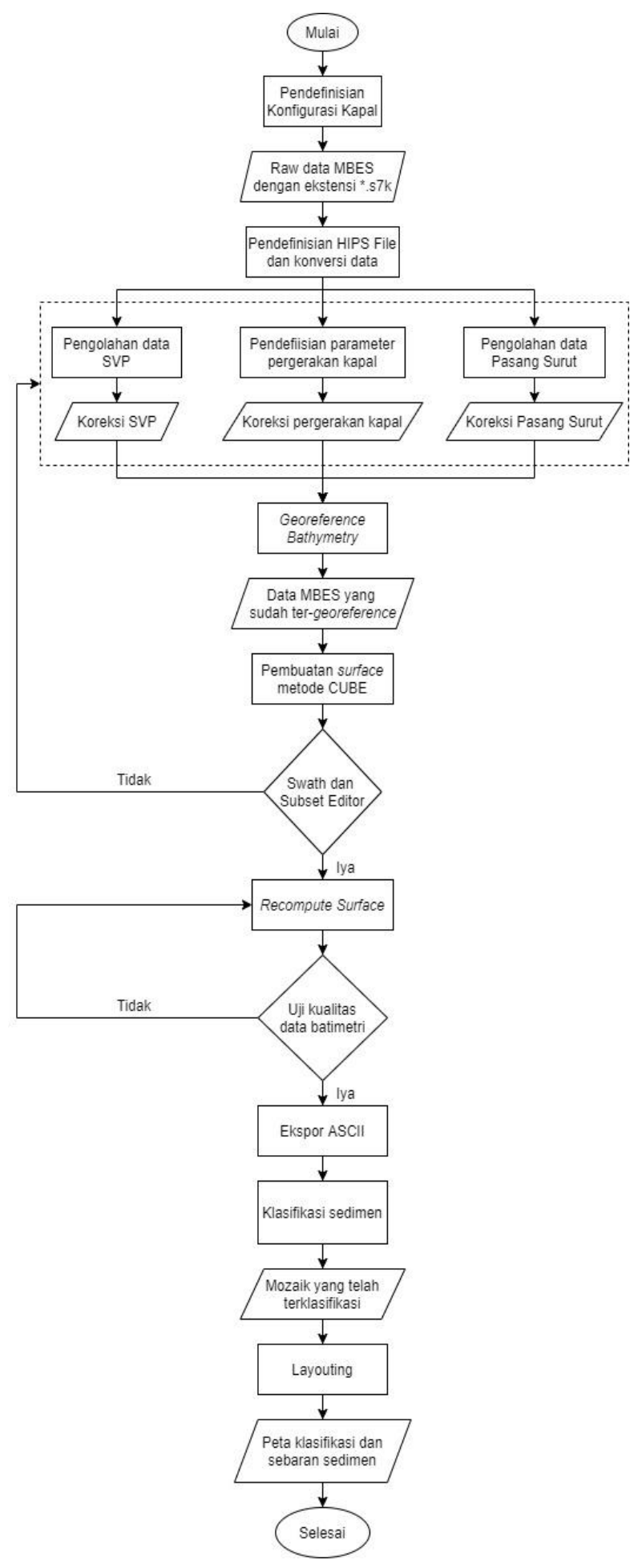

Gambar 3. Diagram Alir Kegiatan

\section{b. Pembuatan HIPS File dan Konversi Data}

HIPS File merupakan wadah project dalam pengolahan data menggunakan software CARIS HIPS and SIPS (Ayuningtyas, 2020). Untuk pembuatan HIPS File perlu di definisikan lokasi output dan sistem referensi horizontal dari data kegiatan. Selanjutnya raw data MBES dengan ekstensi *.s7k dikonversi menjadi HIPS data untuk kemudian disimpan kedalam HIPS File yang sudah dibuat sebelumnya. Hasil konversi akan berupa lajur pemeruman dari tiap set data

\section{c. Georeference Bathymetry}

Pada tahapan georeference bathymetry, data hasil konversi dikoreksikan dengan SVP dan pasang surut yang telah di filter untuk dihilangkan data-data outlayer atau spike juga nilai TPU yang telah di input pada tahapan pendefinisian konfigurasi kapal. Perlu didefinisikan pula sistem referensi vertikal dari data pasang surut dan dimiliki, pada kegiatan ini digunakan chart datum Low Water Spring (LWS) (Ayuningtyas, 2020).

\section{d. Generate Surface menggunakan Teknik Combined Uncertainty and Bathymetry Estimator (CUBE)}

Surface ini merupakan bentuk permukaan dasar perairan area survei. Tahapan pembuatan surface ini hanya dapat dilakukan setelah dilakukannya georeference bathymetry pada data pengukuran. Pemilihan teknik CUBE karena teknik ini mempunyai kelebihan dalam hal proses filtering atau pembersihan noise sehingga dapat menghasilkan permukaan dasar perairan yang lebih halus (Ayuningtyas, 2020).

\section{e. Swath Editor dan Subset Editor}

Pada tahapan pengolahan hasil pengukuran menggunakan MBES pada software CARIS HIPS and SIPS versi 11.2 Training License terbagi menjadi 2 tahapan editing data, yakni swath editor dan subset editor. Menu swath editor ini berfungsi untuk menyaring data salah yang disebabkan oleh lebar pancaran dan batas kedalaman gelombang akustik yang dipancarkan oleh instrumen MBES. Proses swath editor dilakukan secara mendetail pada masing-masing line data pengukuran. Pada menu subset editor dilakukan koreksi data noise. Proses ini dilakukan secara mendetail pada surface, dengan menghilangkan data noise atau data yang terlihat tidak presisi dengan data lainnya agar didapatkan data yang baik dan akurat. Setelah dilakukan editing data, data surface yang merepresentasikan nilai kedalaman harus dilakukan perhitungan ulang dengan menu recompute (Ayuningtyas, 2020).

\section{f. Uji Ketelitian Data Batimetri}

Untuk uji ketelitian data batimetri dipilih 40 pasang sampel titik kedalaman tiap set data. Titik sampel yang dipilih berada pada area overlap antar dua lajur yang diasumsikan memiliki posisi yang sama atau berdekatan. Setelah dihitung beda kedalaman dari pasangan sampel 
yang dipilih, dapat dicari nilai rata-rata dengan Persamaan (1) dan standar deviasinya dengan Persamaan (2). Kemudian dilakukan pengujian kualitas data kedalaman berdasarkan acuan yang telah ditetapkan International Hydrographic Organization (IHO). Dengan tingkat kepercayaan 95\% dihitung nilai simpangan bakunya, berdasarkan tabel Z, sehingga didapatkan nilai dari standar deviasi * 1,96. Nilai tersebut kemudian dibandingkan dengan nilai hasil hitungan pada Persamaan (3).

$$
\begin{aligned}
\hat{H} & =\frac{\sum\left(H_{n}-H_{n-1}\right)}{n} \\
S & =\sqrt{\frac{\sum\left(H_{n}-\hat{H}\right)^{2}}{n-1}} \\
& \pm \sqrt{a^{2}+(b \times d)^{2}}
\end{aligned}
$$

Keterangan:

$\mathrm{S} \quad=$ standar deviasi;

$\mathrm{H}_{\mathrm{n}} \quad=$ kedalaman lajur 2;

$\mathrm{H}_{\mathrm{n}-1} \quad=$ kedalaman lajur 1 ;

$\mathrm{H}^{\wedge} \quad=$ rerata kedalaman;

n = banyaknya sampel;

a = kesalahan independen;

b = faktor kesalahan kedalaman yang dependen;

$\mathrm{d} \quad=$ kedalaman rata-rata;

$(\mathrm{b} \times \mathrm{d})=$ kesalahan kedalaman yang dependen (jumlah semua kesalahan kedalaman yang dependen).

\section{g. Klasifikasi Jenis Sedimen dan Linear Contrast Stretch}

Klasifikasi sedimen terhadap backscatter memerlukan dua tipe data agar dapat dilakukan pengklasifikasiannya, yaitu data backscatter dan data sedimen dasar laut. Data backscatter dependen terhadap sumber akustik, frekuensi, grazing angle, komposisi dasar laut (ukuran butir, kandungan air, densitas, bulk kekasaran dasar laut, dan reverberation volume) pada tiap kedalaman Dartnell \& Gardner (2004). Sedangkan data sedimen laut yang diperoleh diperlukan uji laboratorium untuk menentukan jenis kelas sedimennya pada tiap stasiun pengambilan data untuk mewakili jenis sedimen dasar laut pada area tersebut. Namun pada kegiatan ini, nilai backscatter yang didapat dilakukan koreksi dengan mengadopsi persamaan linear contrast stretch (Mather, 2004) ke rentang nilai backscatter sedimen Nitriansyah \& Cahyono (2018) menggunakan Persamaan (4). Nilai backscatter untuk masing-masing kelas adalah clay dengan rentang backscatter $(-33.81 \mathrm{~s} / \mathrm{d}$ 28) $\mathrm{dB}$, clayey silt dengan rentang backscatter $(-27.99 \mathrm{~s} / \mathrm{d}$ 23) $\mathrm{dB}$, silty clay dengan rentang backscatter $(-22.99 \mathrm{~s} / \mathrm{d}$ 18) $\mathrm{dB}$, dan sand dengan rentang backscatter $(-17.99 \mathrm{~s} / \mathrm{d}$ 10) dB. Hasil klasifikasi divisualisasikan dengan gray scale menggunakan software ArcGIS 10.6.1.

$$
\mathrm{BS}_{\mathrm{c}}=\mathrm{BS}_{\mathrm{i}} \times\left(\frac{\mathrm{BS}-\mathrm{BS}_{\max }}{\mathrm{BS}_{\min }-\mathrm{BS}_{\max }}\right)
$$

Keterangan:

$\mathrm{BS}_{\mathrm{c}} \quad=$ Nilai backscatter yang baru;

$\mathrm{BS}_{\mathrm{i}} \quad=$ koefisien backscatter acuan;

$\mathrm{BS} \quad=$ Nilai backscatter lama;

$\mathrm{BS}_{\max }=$ Nilai backscatter tertinggi;

$\mathrm{BS}_{\min }=$ Nilai backscatter terendah.

\section{h. Export GEOTIFF dan ASCII Data}

Setelah data kedalaman terkoreksi terhadap semua parameter yang ada, maka data tersebut dapat di ekspor ke dalam beberapa format data. Pada kegiatan ini, data hasil ekspor nantinya akan berformat ASCII dengan nilai XYZ sebagai data sounding dan raster GeoTIFF dari hasil surface dengan format *.CSAR.

\section{Hasil dan Pembahasan}

1.1. Pengolahan Data MBES

Hasil pengolahan data MBES dengan melalui proses swath editor dan subset editor menjadikan tampilan surface menjadi lebih halus dari sebelumnya. Hal ini karena dilakukan filtering data-data noise yang melayang atau berada dibawah seabed secara mendetail pada tampilan seabed secara menyeluruh dan bahkan dapat juga dilakukan filtering untuk tiap line nya.

\subsection{Uji Ketelitian Batimetri}

Mengingat lokasi kegiatan yang berada di pelabuhan maka termasuk kedalam orde khusus berdasarkan IHO SP44 tahun 2008. Pada orde ini perhitungan ketelitian kedalaman menggunakan nilai konstanta: $\mathrm{a}=0,25$ dan $\mathrm{b}=$ 0,0075 dan dengan menggunakan Persamaan (3) maka didapat ketelitian setiap titik kedalaman. Untuk Lokasi 1, 2, dan 3 berturut-turut nilai ketelitian nya adalah 0,086247981; 0,131769653; dan 0,10728147. Dengan demikian data hasil pengukuran batimetri pada kegiatan ini merupakan data yang dianggap baik karena nilai (SD * 1.96) $<$ Ketelitian, dan hasil pengukuran diterima dikategorikan ke orde khusus yang merupakan area pengukuran sebenarnya.

\subsection{Topografi Dasar Laut}

Data kedalaman yang ditampilkan pada Gambar 5, Gambar 6, dan Gambar 7 berturut-turut merupakan visualisasi data kedalaman yang mengacu pada aturan Chart No. 1 dari Lokasi 1, Lokasi 2, dan Lokasi 3. Dari gambar tersebut dapat diketahui pula warna putih menandakan area survei yang dalam, dan warna biru menandakan area survei yang dangkal. Pengolahan tersebut dilakukan dengan software ArcGIS 10.6.1. (Ayuningtyas, 2020). 


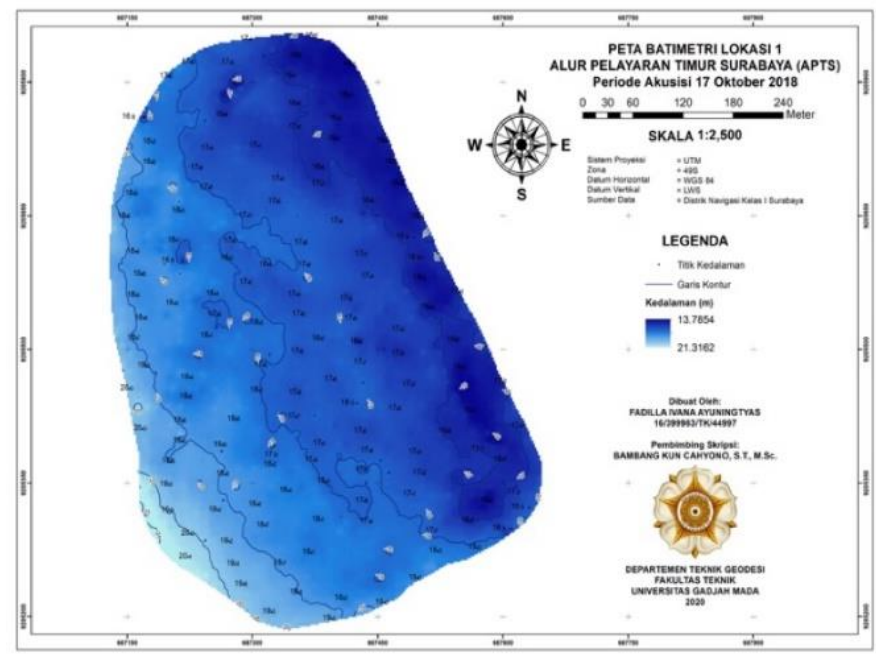

Gambar 5. Layouting Peta Batimetri Lokasi 1 (Sumber: Hasil pengolahan Penulis)

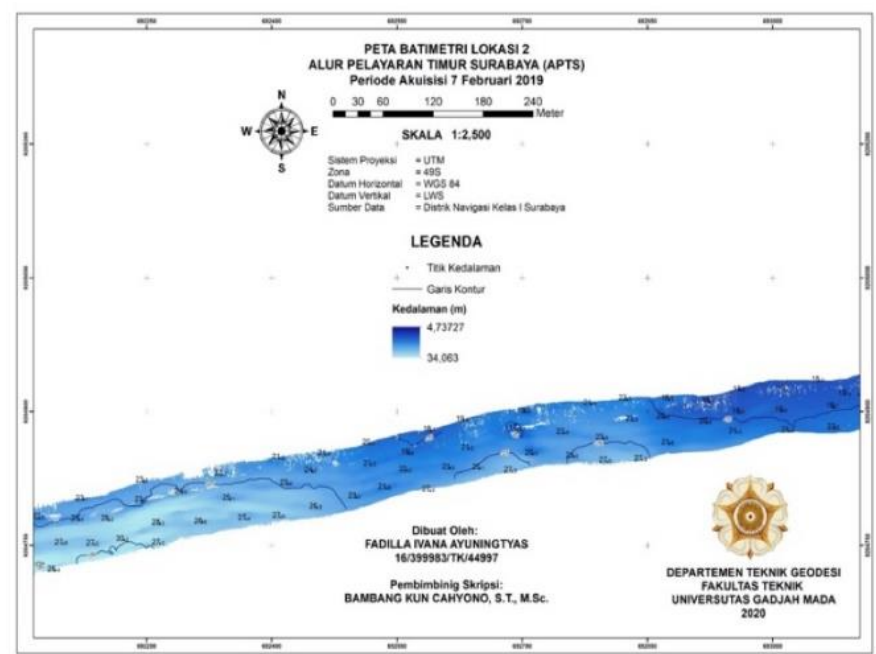

Gambar 6. Layouting Peta Batimetri Lokasi 2

(Sumber: Hasil pengolahan Penulis)

Pada visualisasi topografi dasar laut Lokasi 3 seperti pada Gambar 6, dapat dilihat terdapat area seperti gundukan yang memiliki kedalaman berbeda. Area tersebut dapat dipastikan berupa kerangka kapal yang tenggelam di APBS tetapi telah tertutup sedimen sehingga bentuk asli dari kapal telah tidak terlihat dengan jelas. Data MBES yang didapat dari pengukuran, dapat digunakan juga untuk melakukan identifikasi objek bawah laut yang terdeteksi.

1.4. Klasifikasi Jenis dan Analisis Sebaran Sedimen

Hasil ekstraksi data backscatter tertinggi di Lokasi 1 yaitu -0,8497 dB terletak di 687474.86 BT; 9205611.82 LS pada kedalaman $17,4135 \mathrm{~m}$ dibawah permukaan laut. Dan terendah nya $-63,5767 \mathrm{~dB}$ berada di $687161.86 \mathrm{BT}$; 9205577.82 LS pada kedalaman 19,0122 m dibawah permukaan laut. Untuk Lokasi 2 nilai backscatter tertinggi yaitu $-4,0579 \mathrm{~dB}$ terletak di $690578.17 \mathrm{BT}$; $9204341.43 \mathrm{LS}$ pada kedalaman $14,4518 \mathrm{~m}$ dibawah permukaan laut, terendah $-68,0195 \mathrm{~dB}$ terletak di $693319.17 \mathrm{BT}$; 9204929.43 LS pada kedalaman 20,0814 m dibawah permukaan laut. Sedangkan Lokasi 3 nilai backscatter tertinggi $-17,2368 \mathrm{~dB}$ yang terletak di $691332.40 \mathrm{BT}$; 9237456.80 LS pada kedalaman $4,9115 \mathrm{~m}$ dibawah permukaan laut dan terendah $-94,2472 \mathrm{~dB}$ yang terletak $\mathrm{di}$ 691576.40 BT; 9237266.80 LS pada kedalaman 9,2936 m dibawah permukaan laut.

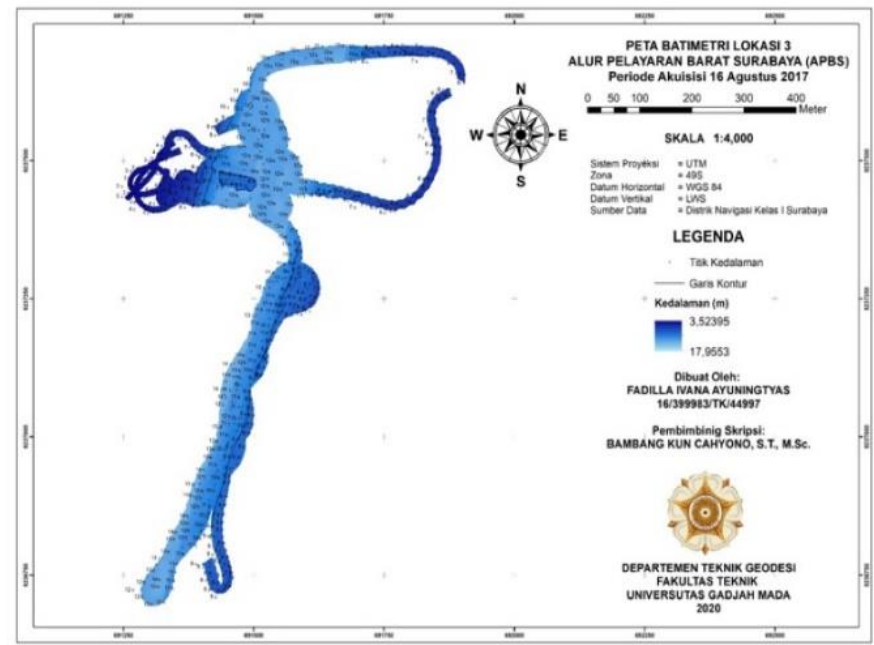

Gambar 7. Layouting Peta Batimetri Lokasi 3

(Sumber: Hasil pengolahan Penulis)

Dengan menggunakan persamaan (4) dilakukan koreksi nilai backscatter yang dimiliki terhadap nilai backscatter yang didapat dari penelitian yang telah dilakukan oleh Nitriansyah \& Cahyono (2018) sehingga klasifikasi nilai backscatter Lokasi 1, Lokasi 2, dan Lokasi 3 berturut-turut menjadi berubah seperti pada Gambar 8, Gambar 9, dan Gambar 10.

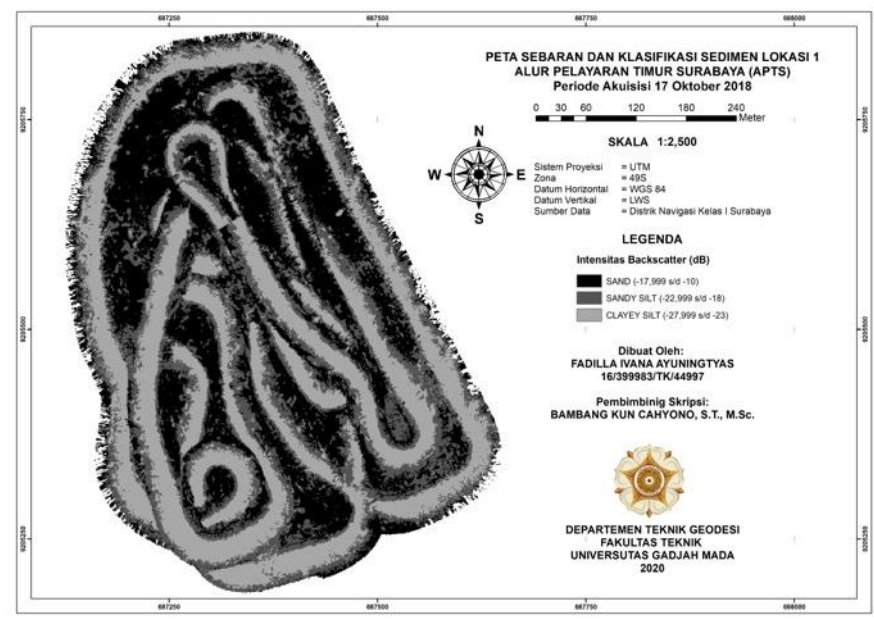

Gambar 8. Hasil visualisasi backscatter dan hillshade Lokasi 1 (Sumber: Hasil pengolahan Penulis) 


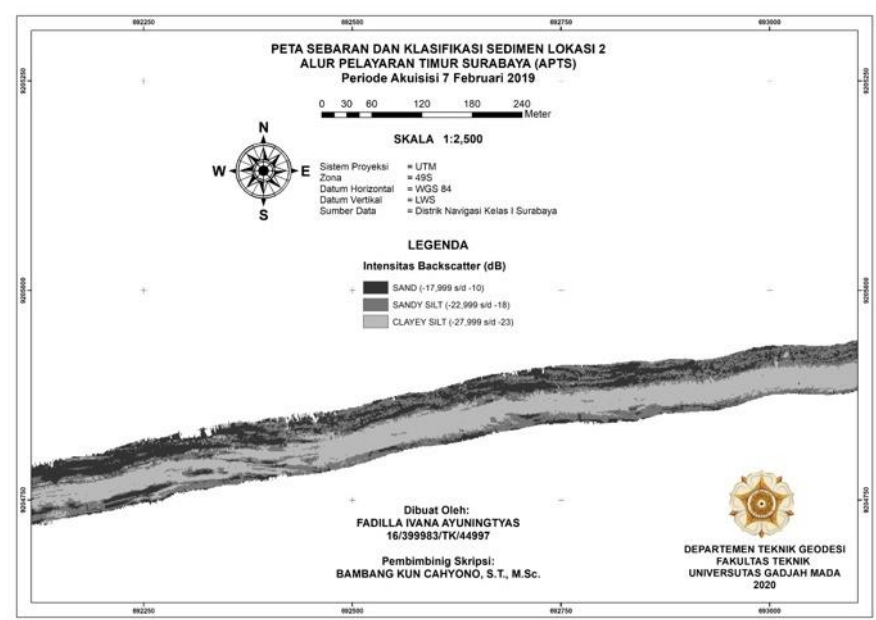

Gambar 9. Hasil visualisasi backscatter dan hillshade Lokasi 2 (Sumber: Hasil pengolahan Penulis)

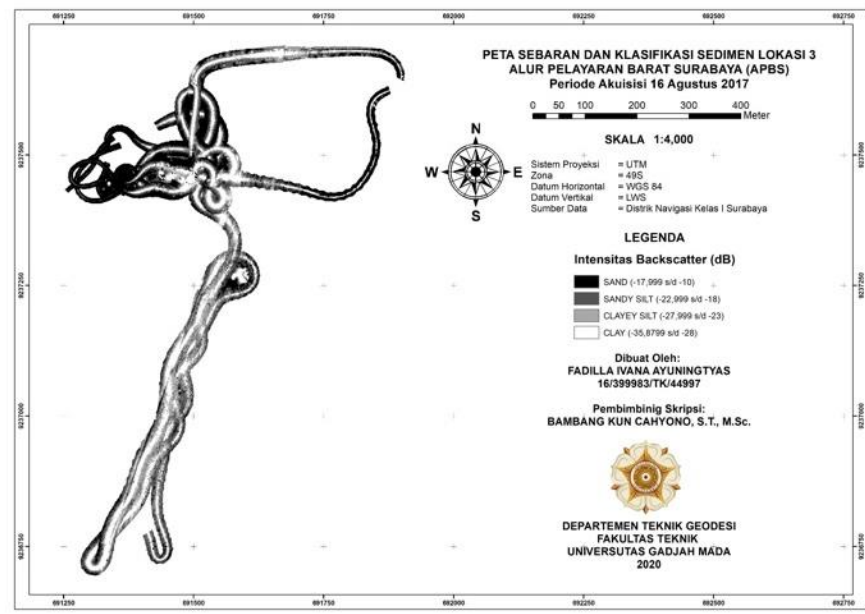

Gambar 10. Hasil visualisasi backscatter dan hillshade Lokasi 3 (Sumber: Hasil pengolahan Penulis)

Tabel 3.1 Hasil sebaran dan klasifikasi sedimen di tiap Lokasi

\begin{tabular}{cccc}
\hline Lokasi & APTS & APTS & APBS \\
\hline Periode & 17 Oktober & 7 Februari & 16 Agustus \\
Akuisisi & 2018 & 2019 & 2017 \\
\hline Pasang & $690527.86 \mathrm{BT} ;$ & $690527.86 \mathrm{BT} ;$ & $701378.89 \mathrm{BT} ;$ \\
Surut & $9203472.41 \mathrm{LS}$ & $9203472.41 \mathrm{LS}$ & $9235637.89 \mathrm{LS}$ \\
\hline & $13,7854-$ & $4,73727-$ & $3,52395-$ \\
Interval & $21,3162 \mathrm{~m}$ & $34,063 \mathrm{~m}$ & $17,9553 \mathrm{~m}$ \\
Kedalam & dibawah & dibawah & dibawah \\
an & permukaan & permukaan & permukaan \\
& laut & laut & laut \\
\hline \multirow{2}{*}{ Back- } & $-10 \mathrm{~dB} \mathrm{~s} / \mathrm{d}-$ & $-10 \mathrm{~dB} \mathrm{~s} / \mathrm{d}-$ & $-16,8539 \mathrm{~dB}$ \\
scatter & $24,3686 \mathrm{~dB}$ & $26,0715 \mathrm{~dB}$ & s/d -36,1243 \\
& & & dB \\
\hline \multirow{2}{*}{ Kelas } & clayey silt, & clayey silt, & clay, clayey \\
Sedimen & sandy silt, & sandy silt, & silt, sandy \\
& dan sand & dan sand & silt, dan sand \\
\hline
\end{tabular}

(Sumber: Hasil pengolahan Penulis)
Berdasarkan hasil overlay yang diperoleh, informasi mengenai sebaran nilai hambur balik di lokasi kegiatan dapat dipetakan. Tampilan overlay yang dihasilkan adalah sebuah citra berwarna hitam gradasi putih. Warna putih merupakan gambaran mengenai kondisi dasar perairan yang memiliki nilai backscatter yang rendah. Warna ini merepresentasikan bahwa pada lokasi tersebut tipe dasar perairan lebih halus dibandingkan kondisi di sekelilingnya. Warna yang lebih gelap menjelaskan bahwa pada kondisi tersebut memiliki nilai backscatter yang lebih tinggi. Nilai backscatter yang tinggi merepresentasikan bahwa di lokasi tersebut, tipe dasar perairan yang ditemui adalah jenis yang relatif kasar. Hasil sebaran dan klasifikasi sedimen di tiap Lokasi disajikan pada Tabel 3.1.

Seringkali data backscatter dan batimetri menunjukkan beberapa efek dari jalur lintasan kapal. Hal ini terutama disebabkan oleh gerakan roll dan heave, profil kecepatan suara yang salah, dan masalah pada normalisasi incidence angle. Seperti yang tampak pada Gambar 8, Gambar 9, dan Gambar 10 lajur lintasan kapal terlihat sangat jelas, namun hal tersebut hanya terjadi pada beberapa area tertentu. Karena masalah pada normalisasi incidence angle tersebut, perlu diketahui sudut incidence angle yang optimal untuk mendapatkan data respon backscatter dan sedimen yang akurat.

Pada Gambar 11 menampilkan beam angle yang terbagi menjadi 3 kelompok yaitu, center beams (nadir beams) dengan incidence angle $0^{\circ}-30^{\circ}$, midrange beams dengan incidence angle $45^{\circ}-65^{\circ}$, dan outer beams dengan incidence angle $75^{\circ}-85^{\circ}$. Nilai backscatter pada outer beams lebih besar dari pada backscatter pada center beams. Pertambahan nilai backscatter ke arah outer beams ini berbanding terbalik dengan nilai standar deviasinya. Hal ini berarti bahwa untuk incidence angle lebih dari $70^{\circ}$ memungkinkan untuk didapatkan hasil klasifikasi sedimen yang akurat (Kagesten, 2008).

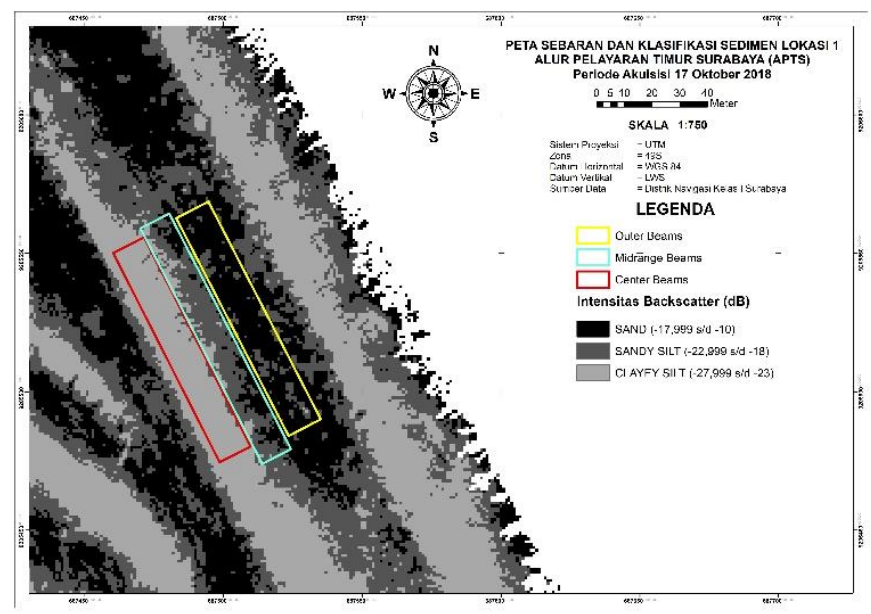

Gambar 11. Incidence beams angle (Sumber: Hasil pengolahan Penulis) 
Masalah pada normalisasi incidence angle tersebut menjadi kendala dari proses klasifikasi jenis sedimen menggunakan nilai backscatter dan data batimetri. Karena beberapa faktor-faktor yang bersumber dari teknis, sifat fisis air laut, dan lokasi kegiatan yang merupakan Alur Pelayaran Barat dan Timur Surabaya yang perairannya sangat terkontaminasi oleh banyak hal, seperti limbah minyak kapal dan lain-lain ikut berpengaruh besar terhadap hasil yang didapatkan. Sehingga untuk mendapatkan hasil yang optimal dalam pengklasifikasian jenis sedimen adalah dengan menggunakan sampel sedimen sebagai ground truth data atau diintergrasikan dengan peralatan hidroakustik lainnya seperti side scan sonar dan sebagainya.

\section{Kesimpulan}

Berdasarkan kegiatan yang telah dilakukan menggunakan alat MBES tipe Odom MB2 di perairan Surabaya diperoleh kesimpulan sebagai berikut:

1. Kualitas data pemeruman menggunakan MBES tipe Odom MB2 yang dilakukan di Alur Pelayaran Barat dan Timur Surabaya dengan kedalaman antara $3 \mathrm{~m}$ hingga $34 \mathrm{~m}$ dibawah permukaan laut dikatakan baik dan memenuhi standar IHO SP-44 tahun 2008 orde khusus dengan nilai (SD * Tabel Z 95\%) untuk Lokasi 1, 2, dan 3 berturut-turut adalah 0,086247981; 0,131769653; dan 0,10728147 .

2. Klasifikasi substrat dasar perairan terbagi menjadi 4 kelas sedimen yaitu tipe clay dengan rentang backscatter $(-33.81 \mathrm{~s} / \mathrm{d}-28) \mathrm{dB}$, clayey silt dengan rentang backscatter $(-27.99 \mathrm{~s} / \mathrm{d}-23) \mathrm{dB}$, silty clay dengan rentang backscatter $(-22.99 \mathrm{~s} / \mathrm{d}-18) \mathrm{dB}$, dan sand dengan rentang backscatter $(-17.99 \mathrm{~s} / \mathrm{d}-10) \mathrm{dB}$. Hubungan tipe dasar perairan jenis sand memberikan nilai backscatter yang lebih kuat dan semakin kecil nilainya seiring dengan bertambah lunaknya tipe dasar perairan.

3. Persebaran sedimen yang terjadi di Alur Pelayaran Barat Surabaya (APBS) yaitu pada Lokasi 3 terdapat 4 tipe sedimen yaitu clay, clayey silt, sandy silt, dan sand. Sedangkan di Alur Pelayaran Timur Surabaya (APTS) yaitu Lokasi 1 dan 2 hanya terdapat 3 tipe sedimen yaitu clayey silt, sandy silt, dan sand.

\section{Pernyataan Konflik Kepentingan}

Penulis menyatakan tidak ada konflik kepentingan dalam artikel ini.

\section{Ucapan Terima Kasih}

Penulis mengucapkan terimakasih kepada pihak Distrik Navigasi (DISNAV) Kelas I Surabaya yang telah memberikan penulis kesempatan untuk melakukan penelitian di Kantor DISNAV Kelas I Surabaya.

\section{Referensi}

Ayuningtyas, F. I. (2020). Klasifikasi Jenis dan Sebaran Sedimen Menggunakan Data Multibeam Echosounder Multi-Temporal di Alur Pelayaran Barat dan Timur Surabaya. Universitas Gadjah Mada.

Brown, C. J., \& Collier, J. S. (2008). Mapping benthic habitat in regions of gradational substrata: An automated approach utilising geophysical, geological, and biological relationships. Estuarine, Coastal and Shelf Science. https://doi.org/10.1016/j.ecss.2007.11.026

Dartnell, P., \& Gardner, J. V. (2004). Predicting seafloor facies from multibeam bathymetry and backscatter data. Photogrammetric Engineering and Remote Sensing, 70(9), 1081-1091. https://doi.org/10.14358/PERS.70.9.1081

Ferrini, V. L., \& Flood, R. D. (2006). The effects of fine-scale surface roughness and grain size on $300 \mathrm{kHz}$ multibeam backscatter intensity in sandy marine sedimentary environments. Marine Geology, 228(14), 153-172. https://doi.org/10.1016/j.margeo.2005.11.010

Goff, J. A., Kraft, B. J., Mayer, L. A., Schock, S. G., Sommerfield, C. K., Olson, H. C., ... Nordfjord, S. (2004). Seabed characterization on the New Jersey middle and outer shelf: Correlatability and spatial variability of seafloor sediment properties. Marine Geology, 209(1-4), 147-172.

https://doi.org/10.1016/j.margeo.2004.05.030

Kagesten, G. (2008). Geological Seafloor Mapping With Backscatter Data From a Multibeam Echosounder. Gothenburg University.

Kim, G. Y., Richardson, M. D., Bibee, D. L., \& Wilkens, R. H. (2004). Sediment Types Determination Using Acoustic Techniques in The Northeastern Gulf of Mexico. Geosciences Journal, 8(1), 95-103.

Mather, P. M. (2004). Computer Processing of RemotelySensed Images. The University of Nottingham, UK. https://doi.org/10.2307/633899

Nitriansyah, R., \& Cahyono, B. K. (2018). Klasifikasi Dasar Laut Menggunakan Data Pengukuran Multibeam Echosounder. (2), 1-9.

Parnum, I., Siwabessy, P. J. W., \& Gavrilov, A. N. (2004). Identification of Seafloor Habitats in Coastal Shelf Waters Using a Multibeam Echosounder. ACOUSTICS 2004. Gold Coast, Australia.

Poerbandono, \& Djunarsjah, E. (2005). Survei Hidrografi. In R. Herlina (Ed.), (R.Herlina, Ed.) (Cetakan Pe). Bandung, Indonesia: PT. Refika Aditama. PT. Refika Aditama.

PUSHIDROSAL. (2019). Peta Laut No. 96 Surabaya. Jakarta. Supartono, B. (2013). Pengukuran Acoustic Backscattering Strength Dasar Perairan Dengan Instrumen Single dan Multi Beam Echo Sounder. Institut Pertanian Bogor.

Sutherland, T. F., Galloway, J., Loschiavo, R., Levings, C. D., \& Hare, R. (2007). Calibration Techniques and 
Sampling Resolution Requirements for

Groundtruthing Multibeam Acoustic Backscatter

(EM3000) and QTC VIEW ${ }^{\mathrm{TM}}$ Classification

Technology. Estuarine, Coastal and Shelf Science, 75,

447-458.

https://doi.org/10.1016/j.ecss.2007.05.045 